\title{
PREDOMINANTLY FEMALE POPULATIONS OF AN AFRICAN BUTTERFLY
}

\author{
D. F. OWEN \\ Department of Zoology, Makerere College, University of East Africa, \\ Kampala, Uganda *
}

Received $19 . x i .65$

IN butterflies the sex ratio is nearly always $\mathrm{r}: \mathrm{r}$. Field collections often contain a slight excess of males over females because the males are the more active and hence are more often seen and collected.

Acraea encedon L. (fig. I) is a common butterfly throughout tropical Africa, inhabiting grassy savanna, forest edge, and the grassy and

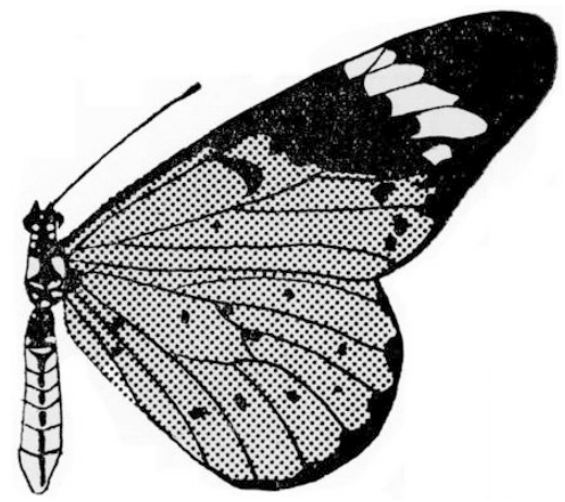

FIG. I.-Acraea encedon. The shaded areas are orange, the remainder black and white, as shown. Males and females are alike in colour and pattern, but the sexes are easily distinguished by the external genitalia. In Uganda, the colour form shown above is the most frequent, but there are many other colour forms involving complete or partial replacement of the orange by white or pale yellow and the replacement of the black and white wing tips with orange.

bushy tops of hills. The larvae feed upon Commelina benghalensis (Commelinaceae). The butterflies are rather slow-flying and form distinct populations that appear to be genetically isolated from each other. A conspicuous feature of the species is its remarkable colour polymorphism: eight to twelve distinct forms may occur together in a population, and, as with other Acraeidae, the species appears to be involved in the large and complex assemblage of Batesian and Müllerian mimetic butterflies that is a feature of the equatorial region of Africa.

\section{METHODS OF STUDY}

All but one of the populations of Acraea encedon studied are in Uganda; the remaining one is at Bukoba, Tanganyika (fig. 2). During

* Present address: Department of Zoology, Fourah Bay College, University of Sierra Leone, Freetown, Sierra Leone. 

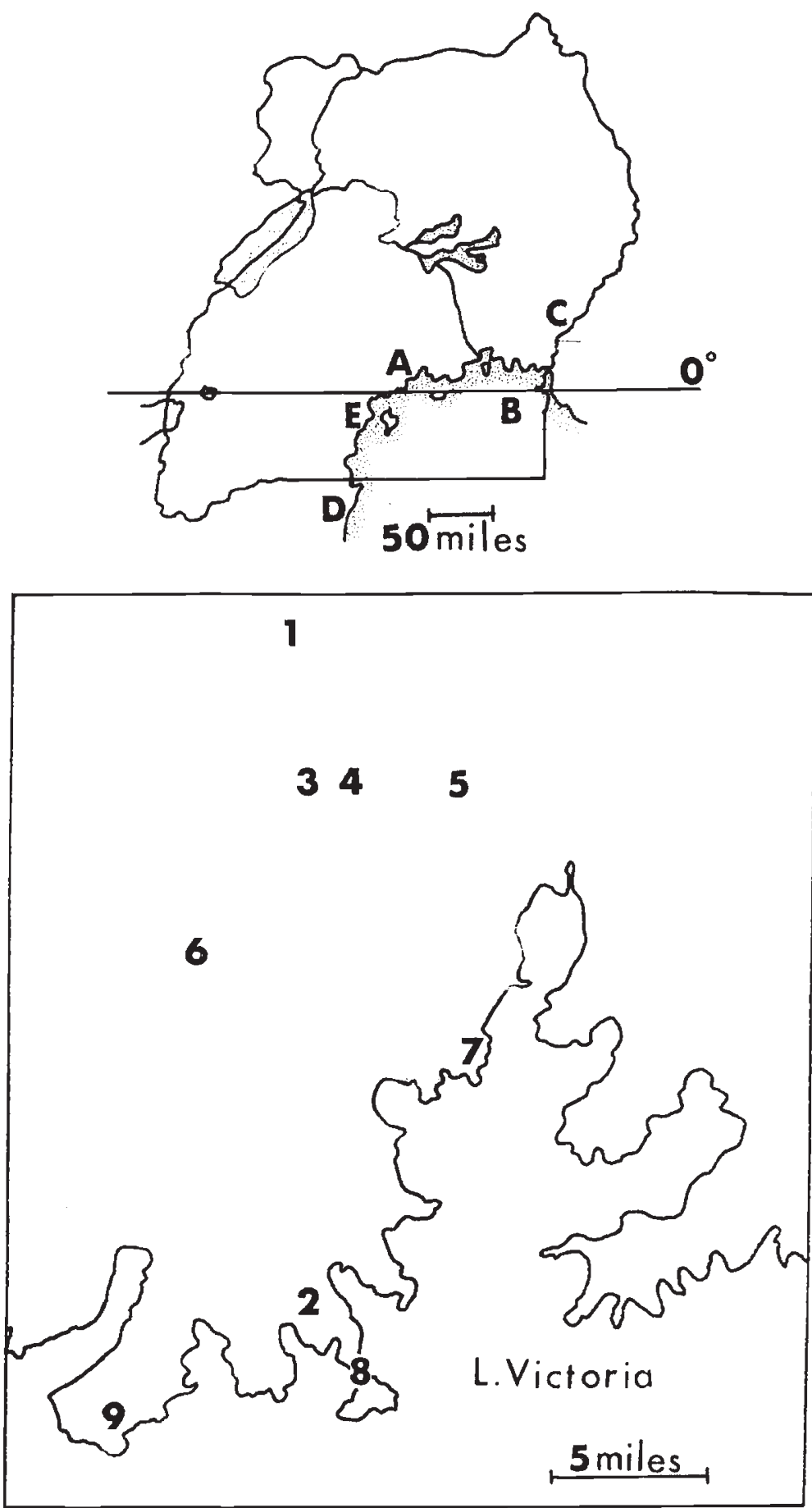

Fig. 2.-Above: A map of Uganda and the adjacent part of western Tanganyika showing location of the populations studied: Kampala-Entebbe area (A), Lolui Island in Lake Victoria (B), Tororo (C), Bukoba, Tanganyika (D), and Nabugabo (E).

Below: Map of the Kampala-Entebbe area showing location of populations studied: Kawanda (1), Nalugala (2), Lubya (3), Makerere (4), Kololo (5), Budo (6), Kazi (7), Kagolomolo (8), and Entebbe (9). 
I $963-65$, adult butterflies were captured, marked with quick-drying coloured ink, and released. The sex and colour-form were recorded, and mated pairs marked distinctly in order to recognise them should they mate again. In some populations specimens were collected and killed. On any one day almost all specimens seen were caught. In Uganda, the butterflies fly throughout the year, but there are fluctuations in numbers that do not appear to be strictly seasonal: populations separated by no more than a few kilometres may be out of synchrony.

Observations on behaviour were made and striking differences between populations were found. Eggs and larvae were collected and adults reared; eggs were also produced by captive females, but it has not been possible to obtain matings in captivity.

\section{SEX RATIOS}

Table I shows the sex ratio in populations of Acraea encedon, and fig. 2 shows the location of the populations.

In the Kampala-Entebbe area the sex ratio is highly abnormal, ranging from only 0.6 per cent. male at Kawanda to 38.6 per cent. male at Entebbe. The overall sex ratio for the nine populations in this area, together with ten other specimens from various localities within the area, is 199 males: 6,667 females. Five of the populations, Kawanda, Lubya, Makerere, Kololo, and Budo, are on grassy hills, and one, Nalugala, is in cultivated coffee and banana country; in these six populations the males are particularly rare. The remaining three populations, Kazi (sometimes spelt Kaazi or Kasi), Kagolomolo, and Entebbe are in flat grassy areas close to lake-shore rain forests; here the males are rather more frequent, but still relatively rare.

Collections were made in the Kampala-Entebbe area of two other species of Acraea. In $A$. pentapolis Ward, $48 \cdot 2$ per cent. were males $(\mathcal{N}=\mathrm{I} 68)$, while in $A$. natalica Boisduval, $56 \cdot 3$ per cent. were males $(\mathcal{N}=128)$. In these two species the sex ratio appears normal, and casual observations suggest that in other Acraea species in the area the sex ratio is normal.

Table I also shows the sex ratio in four other populations of $A$. encedon. These populations are widely scattered (fig. 2) and are well outside the Kampala-Entebbe area. It appears that the sex ratio in them is near $I: I$, the field collections showing a slight excess of males.

Table 2 shows the sex ratio in adult butterflies reared from wildcaught females (including mated pairs) and from eggs and larvae collected in the field in the Kampala-Entebbe area. Only I $\mathrm{I}$ per cent. of the reared butterflies are males, and thus the results from field sampling adult butterflies are confirmed. Indeed of the 63 specimens reared from the Entebbe population only two are males, indicating a lower frequency $(3.2$ per cent.) of males in reared broods than in wild-caught 2 F 2 
specimens from the same population (table I). Evidently, the Kampala-Entebbe area is unusual in the striking scarcity of male Acraea encedon.

TABLE 1

Sex ratios in populations of Acraea encedon

\begin{tabular}{|c|c|c|c|}
\hline & Males & Females & Per cent. male \\
\hline $\begin{array}{l}\text { A. Kampala-Entebbe area } \\
\text { 1. Kawanda } \\
\text { 2. Nalugala } \\
\text { 3. Lubya } \\
\text { 4. Makerere } \\
\text { 5. Kololo } \\
\text { 6. Budo } \\
\text { 7. Kazi } \\
\text { 8. Kagolomolo } \\
\text { 9. Entebbe } \\
\text { Five other localities }\end{array}$ & $\begin{array}{r}5 \\
2 \\
2 \\
38 \\
6 \\
10 \\
31 \\
65 \\
14 \\
27 \\
1\end{array}$ & $\begin{array}{r}815 \\
302 \\
3,092 \\
510 \\
301 \\
570 \\
990 \\
45 \\
43 \\
9\end{array}$ & $\begin{array}{r}0.6 \\
0.7 \\
1.2 \\
1.2 \\
3.2 \\
5.2 \\
6.2 \\
23.7 \\
38.6\end{array}$ \\
\hline Total & 199 & 6,677 & $2 \cdot 9$ \\
\hline $\begin{array}{l}\text { Other populations } \\
\text { B. Lolui Island } \\
\text { C. Tororo } \\
\text { D. Bukoba } \\
\text { E. Nabugabo }\end{array}$ & $\begin{array}{r}15 \\
12 \\
52 \\
3\end{array}$ & $\begin{array}{r}5 \\
9 \\
20 \\
4\end{array}$ & $\begin{array}{l}75 \cdot 0 \\
57 \cdot 1 \\
72 \cdot 2\end{array}$ \\
\hline Total & 82 & $3^{8}$ & $68 \cdot 3$ \\
\hline
\end{tabular}

TABLE 2

Sex ratios in reared broods of Acraea encedon from populations in the Kampala-Entebbe area, $1963-65$

\begin{tabular}{|c|c|c|}
\hline & Males & Females \\
\hline $\begin{array}{l}\text { Reared from mated pairs } \\
\text { 7. Kazi } \\
\text { 4. Makerere } \\
\text { 5. Kololo } \\
\text { 9. Entebbe } \\
\text { Reared from wild caught females } \\
\text { 7. Kazi } \\
\text { 6. Budo } \\
\text { 6. Budo } \\
\text { Reared from eggs collected on } \\
\text { Commelina benghalensis } \\
\text { 9. Entebbe } \\
\text { Reared from larvae collected on } \\
\text { Commelina benghalensis } \\
\text { 9. Entebbe }\end{array}$ & $\begin{array}{l}\bar{z} \\
\overline{-} \\
\bar{E}\end{array}$ & $\begin{array}{r}15 \\
37 \\
19 \\
7 \\
8 \\
25 \\
13 \\
\\
52 \\
\end{array}$ \\
\hline Total & 2 & 178 \\
\hline
\end{tabular}




\section{A CHANGE IN SEX RATIO}

In I000-1 2, C. A. Wiggins collected random samples of $A$. encedon from the Kampala-Entebbe area. The collection is preserved in the Hope Department, Oxford, and comprises 96 males and 54 females, suggesting a near normal sex ratio. In $1963-65$, I 99 males and 6,667 females (table I) were collected from the same general area. The apparent change in sex ratio is highly significant $(P<0 \cdot 00 \mathrm{I})$. (In an earlier report (Owen, I965), the change was stated to be from $64^{\circ} \cdot$ to I. 6 per cent., but since then more information has been obtained.)

It seems that Acraea encedon may have 2-5 generations in a year, depending on weather conditions (in particular, dry weather seems to slow down development), and hence the change in sex ratio may have taken place over I00-250 generations, or more rapidly; indeed two specimens collected at Kawanda, one in 1944 and one in 1952 (in the collection of the Uganda Department of Agriculture), are both males, while in $1963-65$ only five out of 820 Kawanda specimens are males.

The $64^{\circ} 0$ per cent. males in the $1909-12$ collection from KampalaEntebbe does not differ significantly from the 68.3 per cent. males in the $1963-65$ collections from Lolui, Tororo, Bukoba, and Nabugabo, and it would appear that in both collections the sex ratio is normal or near normal.

\section{MODE OF REPRODUCTION}

Clutches of eggs found on Commelina benghalensis at Entebbe all produced viable larvae, as did most of the clutches from wild-caught females, including those from females that were mating when collected, but very few males emerged (table 2). Many of the males collected in the Kampala-Entebbe area were mating at the time of collection, and in view of this it is clear that the species does not depend entirely on parthenogenesis. In addition, single broods often contained a variety of colour forms, and sometimes these were different from the female parent, which would tend to rule out parthenogenesis. But in order to see if parthenogenesis might occur, ten newly emerged and unmated females were placed in breeding cages with plenty of larval foodplant. All produced eggs, but none of the eggs hatched. I feel, therefore, fairly confident that Acraea encedon does not reproduce parthenogenetically.

At Lubya, Budo, and Makerere, repeated marking and releasing showed that males can mate with several different females. One male is known to have mated with four different females, and mating with two females is frequent. Males appear to live about 14 days, and hence it would be possible for a male to mate with fourteen different females during its life assuming that mating takes place once a day, and it is just possible that a male may on occasion mate twice in a day.

Table 3 shows the number of times each male would have to mate if all females are to be mated. It would seem unlikely that all females 
could be mated at Makerere, Lubya, Nalugala, and Kawanda, and possibly also at Budo and Kololo, but at Entebbe and Kagolomolo, and possibly Kazi, all females could be mated assuming that males could mate 2-I 5 times.

After fertilisation, females of Acraea, develop a plug over the genital apparatus that prevents a second fertilisation, and in some species the female's behaviour prevents a second mating (Labine, 1964); but no such mechanism exists in males and theoretically males could mate many times.

TABLE 3

Number of time a male must mate with a different female in order for all females in the population to produce fertilised eggs. Calculated from table I

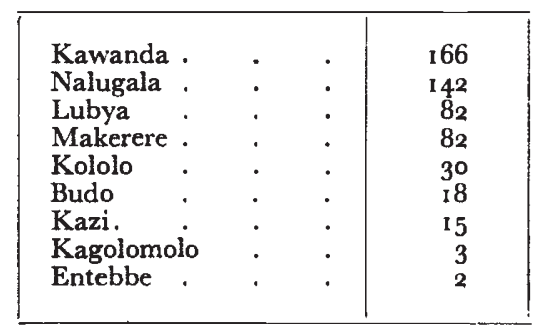

\section{BEHAVIOUR}

In the predominantly female populations, the butterflies often aggregate at a particular site late in the afternoon. Frequently 40 or 50 may be found on a grass flower head, some of them clinging to each other. They frequently fly around each other as if in courtship, but almost all of the butterflies in these aggregations are females. The same site, often no more than a few square metres, is used by the aggregating butterflies day after day and month after month: some sites are known to have been used for over a year. The different sites have little in common, except that they are all exposed to the late evening sun, and all contain low bushes and tall grasses upon which the butterflies can settle. Males sometimes occur in the aggregations, and when they do they are usually mated to a female. There is a strong tendency for each individual to take part in an aggregation only once or twice, but some females are known to have participated for at least io days. The aggregations are most spectacular where the males are at low frequency -Kawanda, Nalugala, Lubya, Makerere, and Kololo. At Budo and Kazi, aggregations are less regular and occur only when there are twenty or more butterflies on the wing. Aggregations do not occur at Kagolomolo and Entebbe, where males are more frequent, nor at Bukoba, where the sex ratio is normal. It would appear that aggregation is associated with, and perhaps determined by, the low frequency of males.

During the late afternoon, when activity is most intense, females 
may deposit eggs on the wings of other females. In May-August 1965, 3,092 females were examined at Lubya and eggs were found on the wings of $30(0.45$ per cent.). Eggs occurred near the edges of the wings, 26 times on a hindwing, three times on a forewing, and once, in two clusters, on a forewing and a hindwing. The frequency of eggs recorded on these 30 females is as follows:

$\begin{array}{lrrrrrrrrr}\text { eggs } & \text { I } & 2 & 3 & 4 & 5 & 6 & 7 & 8 & 9 \cdots \cdots 35 \\ \text { females } & \text { I I } & 7 & 2 & 3 & - & - & 7 & 2 & 2 \ldots \ldots\end{array}$

All eggs laid in this way failed to hatch. Egg-laying on wings also

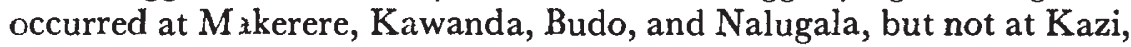
Entebbe, and Kagolomolo. It is clearly associated with aggregating behaviour.

Eggs may also be laid in clusters on vegetation around and on which the butterflies settle while a ggregating. At Lubya, numerous clusters of eggs, often with 50 or more in a cluster, have been found on Lantana camara and Aspilia africana. None of these is a foodplant of A. encedon.

It appears, then, that in populations where the males are scarce, many females are not fertilised and may lay infertile eggs on each other and on plants that happen to be growing at the places selected for aggregating.

\section{DISCUSSION}

It is clear that predominantly female populations of Acraea encedon present some unusual problems in genetics and population ecology. Assuming that the species is not parthenogenetic, many females must fail to produce viable offspring and must contribute nothing to succeeding generations.

One adaptive consequence of the low frequency of males is that there would be little gene flow between populations as there would be already too many females for the males to fertilise, and males would not move from their own population seeking unmated females. Evidence that populations of $A$. encedon are closely adjusted to local conditions is provided by striking differences in the relative frequency of polymorphic forms in different populations. The frequencies of two of these forms are shown in table 4. In form alcippina, the orange of the hindwing (fig. I) is largely replaced by white, and in form lycia all the orange of the wings is replaced by white. These and other genetic forms of $A$. encedon often differ significantly in frequency even between adjacent populations. Thus the 12.9 per cent. difference in the frequency of alcippina at Makerere and Lubya (separated by 2.5 kilometres) is highly significant $(P<0.00 \mathrm{I})$, and there are similar significant differences between other populations. It is evident that $A$. encedon rivals Maniola jurtina in the Scilly Islands (Ford, I964) in its 
local genetic adaptation and response to isolation. And it does seem that the effects of isolation and adaptation can be strengthened in a species in which the males are so rare that they would hardly ever leave their own population and spread their genes elsewhere.

Poulton (1914) has described entirely and predominantly female broods of $A$. encedon from Lagos, Nigeria. He thought that there might be two "strains" of female, one producing females and the other mainly males, and that such a breeding system would promote interbreeding between families. Poulton also mentions a sample of $3^{8}$ females and one male $A$. encedon from Gigbema, Sierra Leone, suggesting a predominantly female population.

TABLE 4

Relative frequency of two colour forms of Acraea encedon in the Kampala-Entebbe area. Sample sizes are given in table 1

\begin{tabular}{|l|c|c|}
\hline & Per cent. alcippina & Per cent. lycia \\
\hline 1. Kawanda & $21 \cdot 6$ & $1 \cdot 0$ \\
2. Nalugala & - & $27 \cdot 0$ \\
3. Lubya & 13.4 & $3 \cdot 5$ \\
4. Makerere & 26.3 & $1 \cdot 0$ \\
5. Kololo & $28 \cdot 0$ & $1 \cdot 0$ \\
6. Budo & $11 \cdot 5$ & $11 \cdot 1$ \\
7. Kazi & 0.7 & $25 \cdot 5$ \\
8. Kagolomolo & - & $22 \cdot 0$ \\
9. Entebbe & - & $22 \cdot 9$ \\
\hline
\end{tabular}

\section{SUMMARY}

I. Some populations of a common tropical African butterfly, Acraea encedon, contain very few males. In Uganda there are populations with less than one male to a hundred females; other populations are normal.

2. There is evidence that the low frequency of males in these populations is of recent origin.

3. In the predominantly female populations there is no evidence of parthenogenesis, but males may mate with several females. During the afternoon the butterflies aggregate at certain places and may lay infertile eggs on each other and on the vegetation upon which they settle. This behaviour does not occur where the sex ratio is normal or nearly normal.

4. One effect of the rarity of males is that populations remain genetically isolated and each population is characterised by a particular frequency of polymorphic colour forms. But many females appear to remain unmated and apparently contribute nothing to succeeding generations.

Acknowledgments.-I am grateful to J. Hall and P. Davies for information about the Budo population, to A. W. R. McCrae for the collection from Lolui Island, and to J. Scheven for collecting and providing information from the Bukoba population. 
D. O. Chanter helped with much of the field work on the other populations. G. C. Varley granted access to the Wiggins collection in the Hope Department, Oxford. The work was supported by a grant from Makerere University College Research Grants Committee.

\section{REFERENCES}

FORD, E. B. 1964. Ecological genetics. London.

LABINE, P. A. 1964. Population biology of the butterfly, Euphydryas editha. 1. Barriers to multiple inseminations. Evol., $18,335-336$.

OWEN, D. F. 1965. Change in sex ratio in an African butterfly. Nature, 206, 744. poulton, z. B. 1914. W. A. Lamborn's breeding experiments upon Acraea encedon (Linn.) in the Lagos District of West Africa, 1910-1912. 7. Linn. Soc. London, 32, $39^{1-416 .}$ 